\title{
Correction to: Understanding and using AlloSure donor derived cell-free DNA
}

\author{
R. K. Seeto ${ }^{1}$ J. N. Fleming ${ }^{2} \cdot$ S. Dholakia $^{3} \cdot$ B. L. Dale ${ }^{4}$ \\ Published online: 1 October 2020 \\ (C) International Union for Pure and Applied Biophysics (IUPAB) and Springer-Verlag GmbH Germany, part of Springer Nature 2020
}

\section{Correction to: Biophysical Reviews (2020) 12:917-924.} https://doi.org/10.1007/s12551-020-00713-5

All authors of the article, "Seeto, R.K., Fleming, J.N., Dholakia, S. and Dale, B.L., 2020. Understanding and using AlloSure donor derived cell-free DNA. Biophysical Reviews, 12, pages 917-924", are employees at CareDx. CareDx provides Allosure.

Publisher's note Springer Nature remains neutral with regard to jurisdictional claims in published maps and institutional affiliations.

The online version of the original article can be found at https://doi.org/ 10.1007/s12551-020-00713-5

$\triangle$ R. K. Seeto

reg.seeto@gmail.com

1 University of Sydney, Sydney, NSW, Australia

2 Medical University of South Carolina College of Pharmacy, Charleston, SC, USA

3 University of Oxford, Oxford, UK

4 Vanderbilt University, Nashville, TN, USA 